\title{
ESP Book Evaluation: The Case of Management Course Book
}

\author{
Maryam Azarnoosh ${ }^{1}$, Maryam Ganji ${ }^{2}$ \\ ${ }^{1}$ Department of English, College of Humanities, Semnan Branch, Islamic Azad University, Semnan, Iran \\ ${ }^{2}$ Department of English, College of Humanities, Semnan Science and Research Branch, Islamic Azad University, Semnan, Iran
}

Email address:

azarnoosh.86@gmail.com (M. Azarnoosh),m.azarnoosh@semnaniau.ac.ir (M. Azarnoosh), Ganji_Maryam290@yahoo.com (M. Ganji)

\section{To cite this article:}

Maryam Azarnoosh, Maryam Ganji. ESP Book Evaluation: The Case of Management Course Book. International Journal of Secondary Education. Vol. 3, No. 3, 2015, pp. 21-25. doi: 10.11648/j.ijsedu.20150303.11

\begin{abstract}
Textbooks are believed to be an essential component of the classrooms. Teachers usually spend a lot of class time on using textbooks and choosing an appropriate one. Therefore, textbook evaluation is important to improve and increase their fitness to the needs and goals. Specifically, in courses of English for specific purposes (ESP), textbooks play an important role on students' future in continuing their field of study and using their English skills in workplaces. This study aimed to evaluate the quality of the English for students of management coursebook. For this purpose, Miekley's (2005) checklist was used to evaluate the book considering five major aspects. Qualitative descriptive analyses were used to evaluate the current textbook based on the guidelines and framework presented in the available checklist. The results indicated that the textbook can be appropriate for management students but should be modified in some cases to fulfill the course goals and encourage students to use what they learn in their future workplace.
\end{abstract}

Keywords: ESP (English for Specific Purposes), Textbook Evaluation, EFL (English for Foreign Language Learners), Management

\section{Introduction}

English is used as an official or semi-official language in over 60 countries (Crystal, 1987, cited in Pennycook, 1994). Without doubt, English has achieved global status since many countries consider it the language to be synonymous with economic success and an international culture. The increasing number of speakers of other languages and considering this fact that there are more people who speak English as a second language than people who speak English as a first language, turned English to a common and application-oriented language which is spread through the world .

Also, Philipson (2001) described English from various perspectives, such as the influence of globalization, finance and the economy connected to Americanization, world trade organization, and so on. Concurrent with using English as the established language of scholarly communication, the rise of English as the language of science remains a topic of debate. Schools and administrators have deep concentration on whether to teach English and familiarize students from the first steps and to place it as one of the main course in both schools and universities.

No one can ignore the paramount function of textbooks in teaching English especially for specific purposes. They form the basis of any courses in this domain. As a matter of fact, English courses covered by textbooks should serve the courses in the best way as much as possible. McGrath (2006) states that "course books tend to dictate what is taught, in what order and, to some extent, how and what learners learn" (p. 171). He considers textbooks as the most important part of teaching, and evaluating textbooks as a task of great importance to the future success of programs. The decision of which textbook to use is an obligatory decision that will affect an entire generation of students, and new and reformed English textbooks can be more sufficient and useful.

There are some ways to evaluate textbooks such as needs analysis process to identify and evaluate needs, interrogating English teachers to find the text books' problems or even comparing new and previous textbooks and find the effect of new methods and materials. In addition, using checklists can play an important role in evaluating books especially in ESP 
courses in which the books are important in preparing students encounter the real context in their future workplace.

\section{Review of Literature}

The term evaluation has been used to define a variety of processes in the field of applied linguistics. Lynch (1996) defined evaluation as "the systematic attempt to gather information in order to make judgments or decisions" (p. 2). Rea-Dickins and Germaine (1994) state that "evaluation is an intrinsic part of teaching and learning." (p. 4) It plays a key role in education and it is important for teachers since it can provide valuable information for classroom practice, planning courses, and management of learning tasks and teaching students. Moreover, evaluation is quite an important part of the educational process. It is essential for the use of instructional materials such as textbooks since they can serve as a syllabus and a self-study source for learners. ReaDickens and Germanie state that "there is a need to evaluate language teaching methods, materials, and their effectiveness as teachers and also how materials are presented to learners, the types of learning tasks used, and the way the courses are designed. They are all part of the curriculum taking place both prior to and during the implementation of a learning program, and they all must be evaluated." (p. 5) They also define evaluation "as the means by which we can gain a better understanding of what's effective, what's less effective and what appears to be no use at all" (p. 28).

They also serve as a support for the beginning teachers who have yet to gain in confidence. Hutchinson (1987) argue that the textbook has a very important and a positive part to play in teaching and learning English. They state that textbooks provide the necessary input into classroom lessons through different activities, readings and explanations. Thus, they will always survive on the grounds that they meet certain needs. Besides, Richards (2001) states that textbooks act as a key component in most language programs. The quality of a textbook might be so important that it can determine the success or failure of an ELT course. Textbooks provide the learners with the necessary input they receive and the language practice that occurs in the class. In addition, textbooks are important in teaching and learning materials and are considered to be the most important part of class activities and exams (Mukundan, 2007).

Teaching materials are playing an important role in the process of learning. Nunan (1998) states that "materials are, in fact, an essential element within the curriculum and do more than simply lubricate the wheels of learning. At their best, they provide concrete models to desirable classroom practice. They act as curriculum models and at their very best they fulfill a teacher development role" ( p. 98).

In addition, textbooks can serve as a reference point for teachers to manage their teaching progress, and to provide a focus for their teaching (Tomlinson 2008). Textbooks can also have a similar function of a map, showing the teaching progress (McGrath 2002)

Textbook evaluation not only helps teachers to develop themselves but also helps them to gain good and useful insights into the nature of the materials. Moreover, it helps in identifying the appropriateness of texts for intended learners (Cunningsworth, 1995). Some textbook authors provide a clear description of their intended subjects, while others are too vague and inappropriate to be applied to a wide range of situations especially for ESP students who expect good materials and course books to help them both in dealing with their future workplace commitments and in providing them with a profound insight of their knowledge to become independent students (Cunnings worth, 1995).

Moreover, as Hutchinson (1987) points out materials evaluation not only serves the immediate practical aim of selecting teaching materials but also plays a critical role in developing teacher's awareness in a number of ways which assist teachers with the analysis of their own presuppositions about the nature of language and learning, forcing teachers to set their prerequisites and helping them to see materials as an essential part of the whole teaching/ learning situation.

Decision related to textbook selection will affect teachers and material developers to more systematic and through examination of potential textbooks and to enhance outcomes for learners, instructors, and administrators. Ellis (1997) maintains that L2 instruction material and textbooks should first be assessed according to predictive standards. The implication here is that L2 teachers would independently evaluate the materials in accordance with one of the numerous established evaluation checklists.

Among different evaluation tools, checklists can play an important role in evaluating books especially in ESP courses to decide if a book is suitable in different aspect to continue its use, discontinue it, or to use another book, or modify it and use supplementary materials. One major advantage of using the checklist approach is that it can provide a very economic and systematic way to ensure all relevant items are considered for evaluation (Cunning worth, 1995; McGrath, 2002). Checklist is a good channel to make different opinions of evaluators explicit. When opinions are explicitly shown based on checklists, they can allow for easy comparison of different sets of textbook materials, and thereby facilitate decision making (McGrath, 2002).

Harmer (1991) suggests that the use of evaluation forms would be useful to see whether it is appropriate for students. Following a quick impressionistic evaluation, detailed checklists can be constructed to perform in depth evaluation of a textbook to enable examination of the appropriateness of the textbook in serving demands of the syllabus and educational needs of students (Cunning worth, 1995).

\section{Methodology}

\subsection{Instrument}

The most popular instruments used for analyzing textbooks are evaluation checklists. In this study, to conduct management textbook evaluation, Miekley's (2005) checklist model was used. As stated by Miekley, each question in this 
checklist is based on recent findings; for example, research findings in the area of effective language learning and critical awareness of strategies employed in language learning (Auerbach \& Paxton, 1997; Salataci \& Akyel, 2002). In addition, it is also constructed based on the elements Byrd (2001) emphasized on, that is the text being a good fit to teacher, students, and the curriculum, all of which are important as educators seek to use materials and methods appropriate to their particular context. This checklist included five main parts which evaluate text books content, vocabulary and grammar, exercises and activities, attractiveness of text and context. Each part consists of a number of questions to be answered when evaluating a book.

\subsubsection{Content}

1. Is the subject matter presented either topically or functionally in a logical, organized manner?

2 . Are the reading selections authentic pieces of language?

\subsubsection{Vocabulary and Grammar}

1. Are the grammar rules presented in a logical manner and in increasing order of difficulty?

2. Are the new vocabulary words presented in a variety of ways (e.g., glosses, multi glosses, and appositives)?

3 . Are the new vocabulary words repeated in subsequent lessons to reinforce their meaning and use?

\subsubsection{Exercises and Activities}

1. Are there interactive and task-based activities that require students to use new vocabulary to communicate?

2. Do instructions in the textbook tell students to read for comprehension?
3. Do the exercises promote critical thinking of the text?

4. Do the activities facilitate students' use of grammar rules by creating situations in which these rules are needed?

\subsubsection{Attractiveness of the Text and Physical Make-Up}

1. Is the cover of the book appealing?

2. Is the visual imagery of high aesthetic quality?

\subsubsection{Context}

1. Does the text coincide with the course goals?

2. Is the textbook appropriate for the students who will be using it?

3. Is the textbook appropriate for the teacher who will be teaching it?

\subsection{Data Analysis}

As mentioned earlier, the present study focused on evaluating a specialized textbook that is English for Students of Management using Miekley's (2005) checklist. This is a self-reporting study using qualitative descriptive analysis. The researcher tried to analyze and evaluate the current textbook based on the guidelines and framework presented in the available checklist. Accordingly, the researcher obtained a full knowledge over the whole content to carefully evaluate the book.

In the following table, content analysis of the textbook has been presented. The table is composed of the questions of the five major parts. Depending on the presence and the quality of each case it was rated as 1-Excellet, 2- Good, 3-adequate, 4- poor, and 5-totally lacking.

Table 1. Content analysis of the book "English for the Students of management".

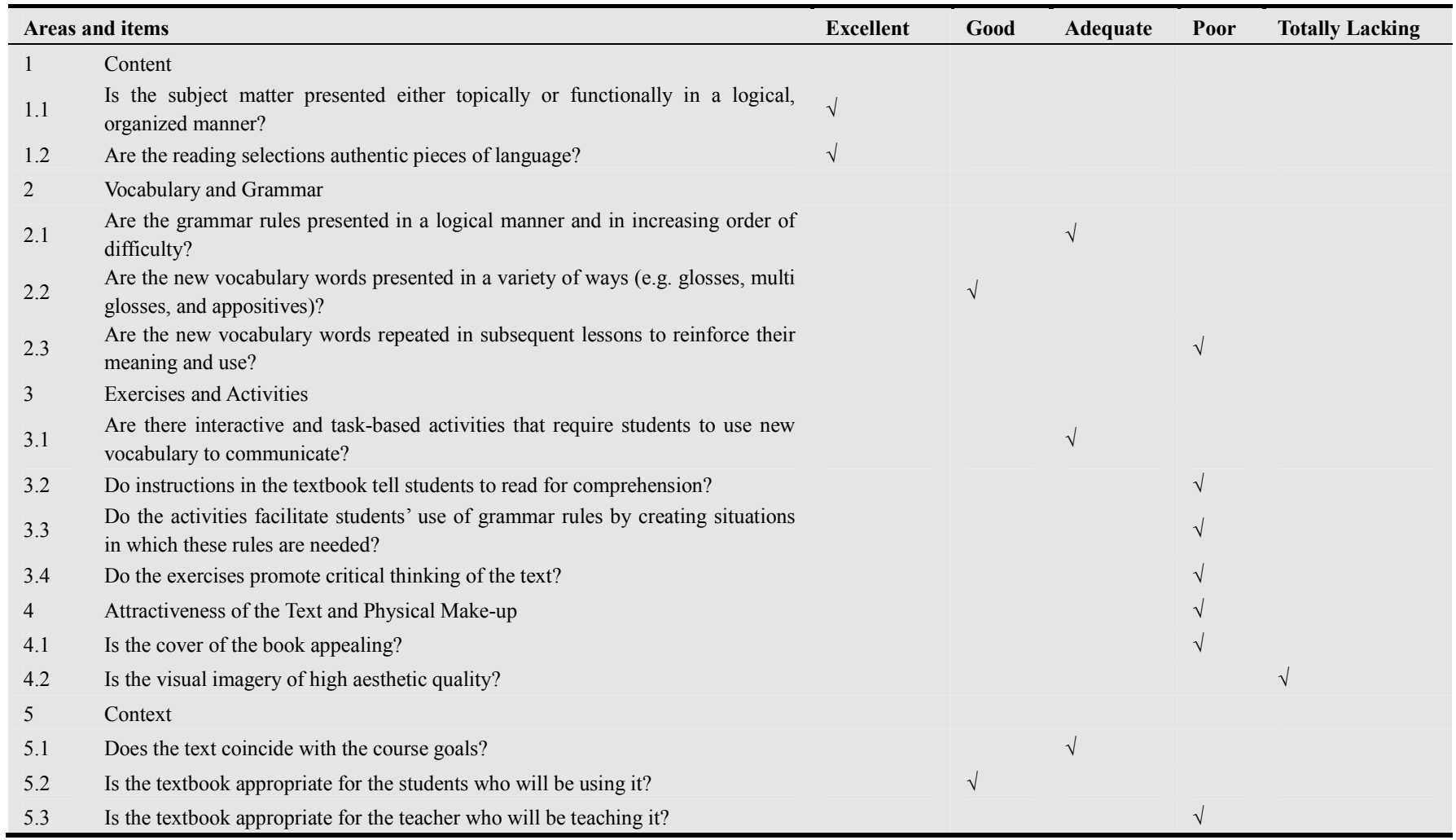




\section{Results}

To evaluate English for Students of Management, all aspects of Miekley's (2005) checklist was considered. Accordingly, the strengths and weaknesses of management book are displayed in five areas of content, vocabulary and grammar, exercises and activities, attractiveness of text and context. What follows is a short description of the findings.

The first aspect to consider is content. The results indicate that the subject matter is topically presented in logical manner, and reading selections include authentic language in a way that students can get familiar with real language use in context. In this book units are organized logically; the book starts with describing the nature of management, science and theory and practice, continues with the managerial decision making processes, pervasiveness and knowledge-based technology, and finally discusses managing organizational conflicts. The texts include authentic pieces of language presenting various types of target situation tasks which try to make a balance between both carrier and real content.

With regard to vocabulary and grammar, the evaluation of the book reveals that grammar rules are presented in a good manner and order and are graded according to their difficulty level from the easiest to the most difficult. Multiple methods of presenting new vocabulary are used, but there are few instances of recycling and repetition of new words. In this book, there are enough references to grammatical rules and some activities are provided to measure them. However, the book may look more valid if some more grammatical items are added to empower students in producing accurate grammatical sentences both in isolation and in communication. Concerning vocabulary, there are also clear references to new vocabulary words. As part of the aims of the book, there is deep concentration on vocabulary, and various activities such as fill in the blanks are provided to put new words under more consideration. In addition, new words are emphasized separately in this book. Nevertheless, the book suffers from poor recycling of new words that is they are not adequately repeated in subsequent lessons to reinforce their meaning and use.

Considering the third aspect, exercises and activities, the book includes a good range of task-based activities. However, it is poor in presenting activities and exercises that encourage students to read for comprehension, to use grammar rules in different situations, and to practice critical thinking of the text. The book prepares variety of activities and exercises which require students to use words and enhance their communication. The exercises include fill in the blanks, truefalse, close- and open-ended questions, answering questions orally, choosing the best alternatives, and so forth. They seem to encourage students to answer the questions and do the tasks according to their individual preferences.

It seems that the book mostly focuses on reading for comprehension, but as a matter of fact, some instructions in the text book do not emphasize on reading for comprehension and this may lead to mechanical answering of the questions. Besides, there are few activities concerned with the application of grammar rules. As mentioned above, the main purpose of most of the activities is to evaluate students' ability to answer the questions rather than grammatical or lexical knowledge. In fact, the exercises seem poor in motivating learners to think critically about the topics. It seems that some modifications in this part can increase learners' autonomy.

The fourth evaluation aspect focuses on the attractiveness of the text and physical make up of the book. In this respect, English for Students of Management does not include any special visual imagery let alone images of high aesthetic quality. In addition, the cover is not attractive enough to encourage students. The appearance of the present book follows the principle of simplicity. It doesn't have colorful pages. It seems that learners' different preferences and learning styles are not sufficiently considered.

With regard to context, the book includes adequate number of texts with the same format and organization, focusing on management theories, frameworks and features. It can be inferred that the goal of the book is just improving reading comprehension. Thus, for this goal the book coincides with the course goal. Moreover, in such books, many new words and technical terms are presented which can raise learners' awareness about their appropriate use in various real contexts and can facilitate their future use. In addition, the book seems easy to be taught by teachers who are specialized in management because of its relevancy to the field; however, the book does not include any guidelines or teacher's manual to assist novice teachers.

\section{Conclusion}

This study aimed at qualitatively evaluating a textbook by using a checklist. Evaluation of the ESP textbook for management students provided a clear understanding of different criteria considering the content, vocabulary and grammar, exercises and activities, attractiveness of text and context of the book.

In general, the textbook can be appropriate for management students who study the book both to improve their knowledge and to use it in real context. On the other hand, the textbook seems to be organized without paying attention to learners' individual differences and learning styles; it lacks visual materials and various activities to reinforce learners' vocabulary and grammatical knowledge. Moreover, no opportunity is provided in the book for students to practice listening, specifically the correct pronunciation of words and sentences. In addition, there is no significant activity to encourage students' writing ability and to motivate them to negotiate and express their ideas.

Thus, modifying some parts of the book can be beneficial to cover all the course goals and encourage students to improve their language knowledge and skills. The findings of the present study bear significant implications for materials 
developers and teachers specifically in applying appropriate supplementary materials to compensate for those areas which need modifications.

Other researchers interested in book evaluation may use other instruments such as interviews besides checklists to analyze textbooks. Moreover, in data gathering they may benefit from both students and teachers points of view.

\section{References}

[1] Auerbach, E. R., \& Paxton, D. (1997). It‘s not the English thing: Bringing reading research into the ESL classroom. TESOL Quarterly, 31 (2), 237-261.

[2] Byrd, P. (2001). Textbooks: Evaluation and selection and analysis for implementation. In M. Celce-Murcia (2nd Ed.), Teaching English as a second or foreign language (pp. 432453). Boston: Heinle \& Heinle.

[3] Cunningsworth, A. (1995). Choosing your Coursebook. London: Macmillan: Heinemann.

[4] Daoud, A.M.\& Celce-Murcia, M. (1979), Selecting and Evaluating Textbooks. In M. Celce-Murcia \& L.Mc-Intosh (Eds.), Teaching English as a Second or Foreign language (pp. 302-307). New York: Newbury House .

[5] Ellis, R. (1997). The empirical evaluation of language teaching materials. ELT Journal, 51(1), (36-42).

[6] Harmer, J. (2001), The Practice of English Language Teaching $\left(3^{\text {rd }}\right.$ ed.). New York: Longman Publishing .

[7] Huthchinson, T (1987). What is underneath? An interactive view of the materials evaluation. In L. E. Sheldon (ed.), ELT textbooks and materials: Problems in evaluation and development, (pp. 37-44), Oxford: Modern English Publications.
[8] Lynch, B. K. (1996) Language Program Evaluation: Theory and Practice. Cambridge: Cambridge University Press.

[9] McGrath, I. (2002). Materials Evaluation and Design for Language Teaching. Edinburgh: Edinburgh University Press.

[10] McGrath, I. (2006) Teachers' and learner's Image of coursebooks. ELT journal, 60, 171-180.

[11] Miekley, J. (2005). ESL textbook evaluation checklist. The Reading Matrix, 5 (2). Retrieved from $\mathrm{http} / / /$ readingmatrix.com/archives/archives_vol5_no $2 . \mathrm{html}$.

[12] Moshfeghi, F. (2011). English for the Students of Management. Tehran: SAMT.

[13] Mukundan, J. (2007). Evaluation of English Language Textbooks: Some Important Issue for Consideration. Journal of NELTA, No1\&2, 80-4

[14] Nunan, D. (1988) Learner-Centered Curriculum. Cambridge: Cambridge University Press.

[15] Pennycook, A.(1994). The cultural politics of English as an International Language. London: Longman.

[16] Philipson. R. (2001). Short Article: English and the World's language. Retrieved 21 may, 2002, from http;//www.hltmag. co.uk/nov01/sartl.htlml.

[17] Rea-Dickens, P. and Germaine, K. (1994). Managing Evaluation and Innovation in Language. 4-5, 28.

[18] Richards, J. C. (2001). The role of textbooks in a language program. Cambridge University Press.

[19] Salataci, R., \& Akyel, A. (2002). Possible effects of strategy instruction on L1 and L2 reading. Reading in a Foreign Language, 14 (1), 1-17.

[20] Tomlinson, B (Ed.) (2008). English Language Learning Materials: A Critical Review. London: Continuum. 